УДК 34

\title{
РОЛЬ МЕДИАТОРА В ПРОЦЕДУРЕ МЕДИАЦИИ
}

\section{Обухова Любовь Александровна}

магистрант

ФГАОУ ВО "Самарский Государственный Экономический Университет" Научный руководитель: Чугурова Татьяна Викторовна

к.П.н., доцент

Аннотация: Статья посвящена актуальным вопросам досудебного разрешения споров между сторонами. Исследуется процедура медиации, ее сущность и значение, основное внимание уделено роли медиатора - как посредника, чья задача - быть объективной и беспристрастной, нейтральной третьей стороной в конфликте, помогая участникам достигнуть мирного соглашения.

Ключевые слова: медиация, медиатор, посредничество, участники конфликта, стороны, спор.

\section{THE ROLE OF THE MEDIATOR IN THE MEDIATION PROCEDURE}

\section{Obukhova Lyubov Aleksandrovna} Scientific adviser: Chugunova Tatyana Viktorovna

\begin{abstract}
The article is devoted to topical issues of pre-trial dispute resolution between the parties. The article examines the mediation procedure, its essence and significance, and focuses on the role of the mediator - as a mediator whose task is to be an objective and impartial, neutral third party in the conflict, helping the participants to reach a peace agreement.

Key words: mediation, mediator, mediation, conflict participants, parties, dispute.

Если исходить из определения понятия «медиация» медиатор является её неотъемлемой частью, и, следовательно, выполняет важную роль в проведении процедуры.

Термин «медиатор» происходит от английского «mediator» и дословно переводится как «посредник».
\end{abstract}




\section{НАУКА, ОБЩЕСТВО, КУЛЬТУРА: ПРОБЛЕМЫ И ПЕРСПЕКТИВЫ ВЗАИМОДЕЙСТВИЯ В СОВРЕМЕННОМ МИРЕ}

Согласно Закону медиатор в России - это независимое физическое лицо, привлекаемое сторонами в качестве посредника в урегулировании спора для содействия в выработке сторонами решения по существу спора.

Медиатор не может являться посредником в силу противоречивости этих понятий. Посредник, согласно российскому законодательству, лицо, которое действует от своего имени, но по поручению и в интересах, а также за счет другого лица. В законе же говорится, о том, что медиатором является независимое физическое лицо. Поэтому хоть два этих понятия в жизни заменяют друг друга, на самом деле не являются как таковыми синонимами.

Затрагивая суть процесса медиации, можно отметить, что данный процесс по своей природе эффективен, направлен на мудрое решение и целесообразное обсуждение возникших проблем. От профессионализма медиатора на 90\% зависит успех дела, в случае, если эмоциональная обстановка спора накалена, до такой степени, что стороны руководствуются, к сожалению, лишь эмоциональной составляющей своего характера.

Профессиональному медиатору стоит руководствоваться своим мастерством и воплотить на переговорах атмосферу полного доверия и взаимопонимания участников рассматриваемого конфликта.

Невозможно быть профессионалом в своей области, не совершенствуя свои навыки. Именно для того чтобы в совершенстве овладеть техникой, необходимо проходить обучение в области медиативного процесса, но и не стоит забывать, что определенного шаблона в процедуре медиации просто не существует, так как вариаций сложившихся спорных ситуации может быть огромное количество и все со своими тонкостями. Стоит затронуть еще не менее важную черту медиатора, это умение организовать благоприятную среду в создании делового и логичного обсуждения ситуации спора, не поддаваясь на провокации и манипуляции.

В научной литературе, а также в практике существует точка зрения, согласно которой, медиатору не стоит вникать в индивидуальные психологические особенности участников, не нужно принимать на себя роль психолога и давать психологические консультации и советы клиенту. Основной целью деятельности медиатора является лишь в возможности оказания помощи участникам в осознании конфликта с разных ракурсов: что послужило исходной причиной конфликта, какие интересы сторон были затронуты и пострадали, к чему может привести конфликт, и какие варианты решения 


\section{НАУКА, ОБЩЕСТВО, КУЛЬТУРА: ПРОБЛЕМЫ И ПЕРСПЕКТИВЫ ВЗАИМОДЕЙСТВИЯ В СОВРЕМЕННОМ МИРЕ}

проблем видят стороны, чтобы избежать судебных разбирательств, решив вопрос мирно в настоящем времени.

Абсолютно непозволительно для медиатора выступать экспертом по техническим вопросам, выражая собственное мнение, советовать что-либо в правовых вопросах, т.е. быть в качестве юриста, примерять на себя роль уполномоченного по правам человека, давая рекомендации участникам, а также выступать в роли судьи, принимая какие-либо решение.

Основным моментом осуществления деятельности медиатора является то, чтобы медиатор сумел помочь поиску оригинальных решений, находя индивидуальный подход к сторонам, создавая условия для того, чтобы участники могли вынести не только положительное решение их вопроса, но и практику недопущения подобных ситуаций. Конечно, закон не устанавливает обязательных требований к кандидатуре медиатора, однако, представляется, что наиболее эффективным будет являться та процедура, которая проводится все-таки профессионалом.

Выше уже упоминалось, что медиаторами могут становиться как на профессиональной, так и на непрофессиональной основе. Но стоит учитывать тот факт, что если спор будет передан на рассмотрение суда общей юрисдикции или третейского суда, то речь о привлечении к участию в процедуре может идти только профессиональном медиаторе.

Но, при любых условиях, деятельность медиатора в современном мире может осуществлять абсолютно любой человек, профессионалом какой сферы он не являлся бы, будь то врач или оператор-машинист, далекий от юридической направленности. Конечно, это не плохо, когда человек может найти себя в разных сферах жизни, не имея при этом конкретного образования этого направления, но все же, когда речь идет о разрешении юридических вопросов, то для развития дальнейшего уровня медиации и повышения доверия со стороны граждан к данной процедуре, стоит задуматься о необходимости ввести наличия высшего юридического образования у медиатора - внести изменения в ст. 16 Федерального закона №193-Ф3.

Деятельность медиатора и его правовой статус регламентируются Федеральным законом №193-Ф3 «Об альтернативной процедуре урегулирования споров с участием посредника (процедуре медиации)», Гражданским кодексом РФ, Арбитражным процессуальным кодексом РФ, Гражданским процессуальным кодексом РФ, Федеральным законом от 24.07.02 №102-Ф3 "О третейских судах в Российской Федерации" и Федеральным 


\section{НАУКА, ОБЩЕСТВО, КУЛЬТУРА: ПРОБЛЕМЫ И ПЕРСПЕКТИВЫ ВЗАИМОДЕЙСТВИЯ В СОВРЕМЕННОМ МИРЕ}

законом от 13.03.06 №38-Ф3 "О рекламе". Медиатор может осуществлять свою деятельность как на профессиональной, так и не на профессиональной основе.

На практике в Российской Федерации используется способствующая модель медиации, предусматривающая, что роль медиатора в процедуре заключается именно в возможности организовать и провести переговоры между сторонами конфликта. При этом медиатор, на протяжении всего периода процедуры, остается независимым и беспристрастным участником медиации, акцентируясь на равноценности оказываемого внимания сторонам спора, помогая при выработке решений и достижении соглашения абсолютно в равном соотношении. Отсюда основной задачей медиатора является обеспечение сторонам достижения взаимовыгодного соглашения.

На основании вышеизложенного в статье, можно говорить о том, что проведение процедуры медиации без участия медиатора просто невозможно. Медиатор может осуществлять свою деятельность, как на профессиональной, так и на непрофессиональной основе. Участники процедуры медиации самостоятельно или на рекомендательной основе отдают предпочтение одной из кандидатур медиаторов, осуществляющий деятельность по обеспечению проведения процедуры. Обращая внимание на действующую модель в России, то целью деятельности медиатора является помощь сторонам в достижении соглашения и примирения. В течение всей процедуры медиатор является организатором процесса, выслушивая мнения сторон, выполняет аналитическую функцию, содействуя в точности оценки сложившейся ситуации и определяя их действительные интересы, однако, в некоторых случаях медиатор, формируя в своем понимании произошедшую ситуацию и возможные выходы их неё, предлагает свои варианты решения конфликта. Деятельность медиатора всегда осуществляется на основе принципов медиации. Согласно Кодексу медиаторов России ст. 3, деятельность медиатора основывается на принципах конфиденциальности, беспристрастности и независимости, открытости, уважении участников, ответственности, добросовестности и профессиональности.

Ролью медиатора является не просто помощь в достижении договоренности между сторонами, но и в заботе, для того чтобы эти договоренности были соблюдены в полной мере, не нарушая политику и принципы конфликтующих сторон. Только таким образом, стороны будет полностью удовлетворены, а деятельность медиатора не пройдут бесследно и безрезультатно. 


\section{Список литературы}

1. Федеральный закон "Об альтернативной процедуре урегулирования споров с участием посредника (процедуре медиации)" от 27.07.2010 N 193-Ф3 (последняя редакция).

2. Гайденко-Шер Н.И. Обязательная медиация: опыт Италии // Третейский суд. - 2012. - № 1. - С. 156-165.

3. Понасюк Медиация и адвокат. Новое направление адвокатской практики / Понасюк. - М.: Инфотропик Медиа, 2016. - 205 с. 